\title{
OPTIMASI KEBUTUHAN ANGKUTAN SAMPAH DI KOTA AMBON
}

\author{
St. Maryam H ${ }^{1}$, Lambang Basri ${ }^{2}$, Titien Layn ${ }^{3}$ \\ ${ }^{1}$ Dosen Jurusan Teknik Sipil Universitas Muslim Indonesia (UMI) \\ Jalan Urip Sumoharjo No.225 Makassar, Telp. 454534 \\ ${ }^{2}$ Dosen Jurusan Teknik Sipil Universitas Muslim Indonesia (UMI) \\ Jalan Urip Sumoharjo No.225 Makassar, Telp. 454534 \\ ${ }^{3}$ Mahasiswa Program Pascasarjana Magister Teknik Sipil UMI . \\ Jl Urip Sumoharjo No.225 Makassar,Telp.454534, ltitien@gmail.com
}

\begin{abstract}
ABSTRAK
Sampah merupakan limbah yang timbul dari aktivitas manusia, baik di rumah, kantor pasar, tempat umum dan sebagainya. Besar - kecilnya volume sampah dipengaruhi oleh tingkat ekonomi dan budaya konsumsi suatu masyarakat. Semakin tinggi kemampuan ekonominya, semakin tinggi pula tingkat konsumsi yang akan berdampak pada semakin besarnya volume sampah yang dihasilkan. Tujuan dari penelitian ini adalah untuk mengetahui jumlah dump truck, pick up truck dan arm roll truck yang dibutuhkan untuk dapat mengangkut sampah di Kota Ambon. Data - data yang dikumpulkan dalam penelitian ini adalah data survey jumlah sampah yang dihasilkan Kota Ambon per hari, kapasitas truk pengangkut sampah, waktu memuat dan menurunkan sampah, waktu perjalanan dan jarak perjalanan. Dari penelitian tersebut diperoleh hasil bahwa jumlah angkutan sampah yang dibutuhkan untuk mengangkut sampah dengan volume sebanyak $1176,82 \mathrm{~m}^{3}$ adalah : 16 dump truck, 7 pickup truck, dan 8 armroll truck, dengan waktu ritasi masing - masing adalah: 3 ritasi untuk dump truck per hari, 2 rItasi untuk pick up per hari, dan 4 ritasi untuk armroll truck per hari.
\end{abstract}

\section{Kata kunci: Sampah, Sistem transportasi angkutan sampah.}

\section{PENDAHULUAN}

\subsection{Latar Belakang}

Sampah merupakan konsekuensi dari adanya aktifitas manusia. Setiap aktifitas manusia pasti menghasilkan sampah. Jumlah atau volume sampah sebanding dengan tingkat konsumsi kita terhadap barang/material yang kita gunakan sehari-hari. Demikian juga dengan jenis sampah, sangat tergantung dari jenis material yang kita konsumsi. Oleh karena itu pengelolaan sampah tidak bisa lepas dari "pengelolaan" gaya hidup masyarakat. Pemahaman dan kesadaran untuk megelola sampah yang dihasilkan dengan tepat, dimulai dari lingkungan terkecil sampai kepada lingkungan yang besar, akan berdampak pada peningkatan kualitas lingkungan yang lebih baik.

Permasalahan sampah yang terjadi di Kota Ambon tidak jauh berbeda dengan kota-kota lain di Indonesia. Pada umumnya faktor yang mempengaruhi pengangkutan sampah adalah kepadatan penduduk, kuantitas dan kualitas sampah, karakteristik serta area pelayanan. Namun, faktor jarak, sistem pengangkutan, jenis kendaraan, frekuensi serta tenaga kerja juga berperan dalam proses pengangkutan sampah.

Tahun 2016 Jumlah penduduk Kota Ambon sebanyak 427.934 jiwa (Kota Ambon dalam Angka 2017). Volume sampah yang dihasilkan rata-rata per hari adalah $1176,82 \mathrm{~m}^{3}$. 
Tabel. 1.1 Produksi sampah Kota Ambon

\begin{tabular}{|c|c|c|c|c|}
\hline Tahun & $\begin{array}{c}\text { Jumlah Penduduk } \\
\text { (jiwa) }\end{array}$ & $\begin{array}{c}\text { Volume } \\
\text { sampah } \\
\text { (m3/hari) }\end{array}$ & $\begin{array}{c}\text { \% Layanan } \\
\text { pengangkutan } \\
\text { sampah }\end{array}$ & $\begin{array}{c}\text { Volume sampah } \\
\text { terangkut } \\
\text { (m3/hari) }\end{array}$ \\
\hline 2012 & 354464 & 974.78 & 35.10 & 342.15 \\
\hline 2013 & 372330 & 1023.91 & 35.50 & 363.49 \\
\hline 2014 & 395423 & 1087.41 & 38.90 & 423.00 \\
\hline 2015 & 411617 & 1131.95 & 40.20 & 455.04 \\
\hline 2016 & 427934 & 1176.82 & 50.64 & 595.94 \\
\hline
\end{tabular}

Sumber : Kota Ambon dalam Angka, 2017

\subsection{Rumusan Masalah}

1. Bagaimana sistem pengangkutan sampah dari Tempat Pembuangan Sementara (TPS) ke Tempat Pembuangan Akhir (TPA) di Kota Ambon?

2. Berapa jumlah angkutan sampah dan ritasi yang dibutuhkan agar sampah yang masuk di TPS dapat terangkut ke TPA?

3. Berapa kebutuhan kendaraan angkutan sampah sampai dengan tahun 2036 ?

\subsection{Tujuan Penelitian}

1. Menganalisis sistem pengangkutan sampah dari Tempat Penampungan Sementara (TPS) ke Tempat Pembuangan Akhir (TPA) di Kota Ambon.

2. Mengoptimasi jumlah ritasi angkutan sampah.

3. Mengetahui kebutuhan angkutan sampah sampai dengan tahun 2036 ?

\section{METODE PENELITIAN}

\subsection{Jenis Penelitian}

Penelitian ini bersifat deskriptif dengan analisis kuantitatif, yang mana penelitian akan dlakukan dengan metode survey dan observasi langsung di lapangan guna mengetahui jumlah volume sampah, jumlah TPS, jumlah ritasi per hari dan jumlah angkutan sampah yang beroperasi. Selain itu, peneliti melakukan wawancara dengan kepala bidang pengelolaan sampah Dinas Lingkungan Hidup dan Persampahan Kota Ambon, Bapak F. Mahulette, S.Sos, Kepala Satuan Kerja Penyehatan Lingkungan Permukiman (Satker PLP) Provinsi Maluku Kementerian Pekerjaan Umum dan Perumahan Rakyat Ibu L. Labobar, ST, MSi.

\subsection{Lokasi Penelitian}

Lokasi penelitian adalah Kota Ambon, dengan berkoordinasi dengan Instansi Pemerintah yang menangani masalah sampah, diantaranya adalah :

Dinas Lingkungan Hidup dan Kebersihan Kota Ambon,

$>$ Unit Pelaksana Teknik Dinas Tempat Pembuangan Akhir (TPA) Toisapu,

$>$ Dinas Pekerjaan Umum dan Perumahan Rakyat Provinsi Maluku dalam hal ini dengan Satuan Kerja Penyehatan Lingkungan Permukiman (Satker PLP) Provinsi Maluku. 


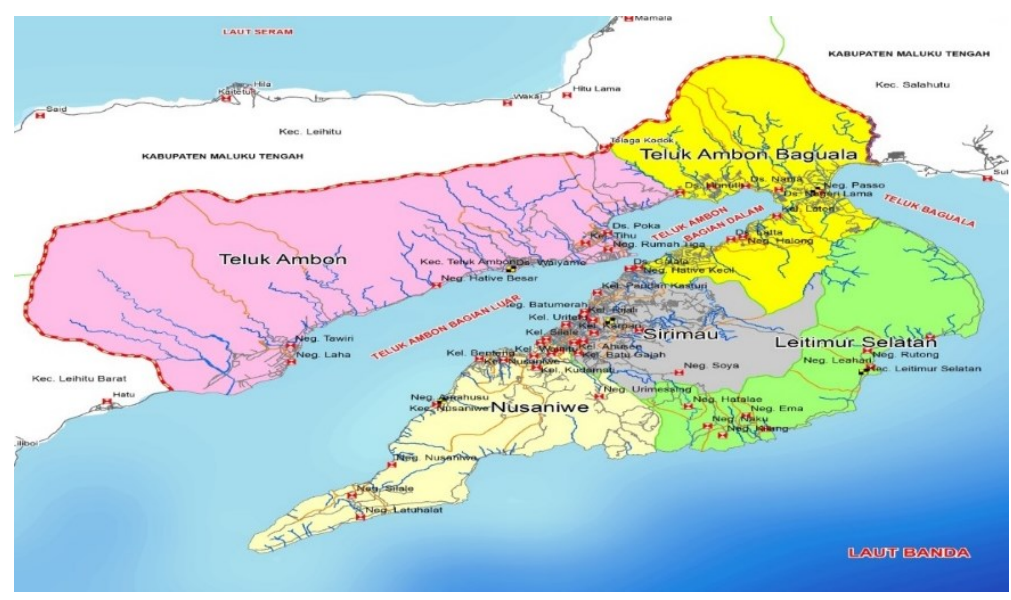

\section{HASIL PEMBAHASAN}

\subsection{Jumlah Kendaraan Pengangkut Sampah di Kota Ambon}

Operasional pengangkutan sampah di Kota Ambon dilakukan oleh Dinas Lingkungan Hidup dan Persampahan Kota Ambon. Prasarana sampah yang tersedia adalah 21 unit mobil dump truck, 6 unit mobil pick up, 6 unit mobil arm roll yang masing-masing mengoperasikan 2 unit container (tabel 4.10). Semua kendaraan pengangkut sampah tersebut beroperasi setiap hari, dump truck dan armroll beroperas dari pukul 03.00 WIT - pukul 08.00 WIT, sedangkan pickup dari pukul 5.00 WIT - 8.00 WIT. Sampah yang diangkut ke TPA adalah sampah rumah tangga, perkantoran, sekolah, dan fasilitas umum (pertokoan, pasar, dan terminal). Sampah medis dari sarana kesehatan biasanya ditangani tersendiri oleh petugas medis.

\section{Tabel 4.9 Kendaraan Operasional Persampahan Kota Ambon}

\begin{tabular}{|c|c|c|c|c|c|}
\hline \multirow[b]{2}{*}{ No } & \multirow[b]{2}{*}{ Kendaraan } & \multirow[b]{2}{*}{ Jumlah } & \multicolumn{3}{|c|}{ Kondisi } \\
\hline & & & Baik & $\begin{array}{l}\text { Rusak } \\
\text { Ringan }\end{array}$ & $\begin{array}{l}\text { Rusak } \\
\text { Berat }\end{array}$ \\
\hline 1 & Dump Truck & 21 & 21 & 0 & 0 \\
\hline 2 & Mobil Armroll & 7 & 6 & 0 & 1 \\
\hline 3 & Mobil Pick Up & 8 & 6 & 0 & 2 \\
\hline 4 & Sepeda Motor 3R & 10 & 8 & 2 & 0 \\
\hline 5 & Speed Boat & 3 & 3 & 0 & 0 \\
\hline
\end{tabular}

Sumber : Dinas Lingkungan Hidup dan Persampahan Kota Ambor

\subsection{Pelayanan Angkutan Sampah}

Presentase pelayanan sistem pengangkutan sampah eksisting, dapat dilihat pada tabel berikut :

Tabel 4.11. Persentase pelayanan angkutan sampah di Kota Ambon Tahun 2016

\begin{tabular}{|c|c|c|c|c|c|}
\hline No & Kecamatan & $\begin{array}{l}\text { Jumlah } \\
\text { Penduduk }\end{array}$ & $\begin{array}{c}\text { Volume } \\
\text { Sampah } \\
\left(\mathrm{m}^{3} / \mathrm{hari}\right)\end{array}$ & $\begin{array}{c}\text { Presentase } \\
\text { Layanan } \\
(\%)\end{array}$ & $\begin{array}{c}\text { Vol. Sampah } \\
\text { Terangkut dari TPS }\end{array}$ \\
\hline 1 & Nusaniwe & 112510 & 309,40 & 51,54 & 166,59 \\
\hline 2 & Baguala & 73644 & 202,52 & 57,14 & 123,87 \\
\hline 3 & Leitimur Selatan & 11862 & 32,62 & 0,00 & 0,00 \\
\hline
\end{tabular}




\begin{tabular}{|r|l|r|r|r|r|}
4 & Teluk Ambon & 51307 & 141,09 & 40,00 & 61,22 \\
\hline 5 & Sirimau & 178611 & 491,18 & 51,43 & 244,32 \\
\hline & & $\mathbf{4 2 7 9 3 4}$ & $\mathbf{1 1 7 6 , 8 2}$ & $\mathbf{5 0 , 6 4}$ & $\mathbf{5 9 5 , 9 9}$ \\
\hline
\end{tabular}

Sumber : Dinas Lingkungan Hidup dan Kebersihan Kota Ambon

\subsection{Analisis Pengelolaan Angkutan Sampah Eksisting}

Pengangkutan sampah di Kota Ambon dilakukan dengan dua sistem yaitu : Sistem kontainer tetap / Stationary Container System (SCS) dan Sistem kontainer angkat / Hauled Container System (HCS).

\section{HCS ( Hauled Container System) / Sistem Kontainer Angkut}

Waktu yang dibutuhkan untuk mengangkut sampah adalah 3,3 jam - 4 jam untuk 2 kali ritasi dan 5,3 jam - 5,8 jam untuk 3 kali ritasi. Volume sampah terangkut sekitar $90 \mathrm{~m}^{3}-105 \mathrm{~m}^{3} /$ hari, dengan kapasitas kontainer $6 \mathrm{~m}^{3}-7 \mathrm{~m}^{3} /$ container, sebagaimana terlihat pada tabel berikut :

\begin{tabular}{|c|c|c|c|c|c|c|c|c|c|c|c|c|c|c|c|c|c|c|c|}
\hline \multirow[b]{2}{*}{ No } & \multirow[b]{2}{*}{ Supir Armroll } & \multicolumn{3}{|c|}{ RUTEI } & \multirow[b]{2}{*}{$\left|\begin{array}{l}\text { Waktu } \\
\text { di TPA }\end{array}\right|$} & \multicolumn{4}{|c|}{ RUTEIII } & \multirow[b]{2}{*}{$=\begin{array}{l}\text { Waktu } \\
\text { di TPA }\end{array}$} & \multicolumn{4}{|c|}{ RUTEIII } & \multirow[b]{2}{*}{ Waktu } & \multirow[b]{2}{*}{$\begin{array}{l}\text { TPA- } \\
\text { TPS1 }\end{array}$} & \multirow[b]{2}{*}{$\begin{array}{c}\text { Waltu } \\
\text { Letak } \\
\text { kontai } \\
\text { ner }\end{array}$} & \multirow[b]{2}{*}{$\begin{array}{l}\text { TPS1- } \\
\text { Pool }\end{array}$} & \multirow[b]{2}{*}{$\begin{array}{l}\text { TOTAL } \\
\text { WAKTU } \\
\text { (jaml) }\end{array}$} \\
\hline & & POOL- & $\begin{array}{c}\text { Waktu } \\
\text { Angkut } \\
\text { Kontai } \\
\text { ner }\end{array}$ & $\begin{array}{c}\text { TPS1- } \\
\text { TPA }\end{array}$ & & $\begin{array}{l}\text { TPA- } \\
\text { TPS2 }\end{array}$ & $\begin{array}{c}\text { Wakttu } \\
\text { Letak } \\
\text { kontai } \\
\text { mer }\end{array}$ & \begin{tabular}{|c|} 
Walktu \\
Angkut \\
Kontai \\
merr
\end{tabular} & $\begin{array}{c}\text { TPS 2- } \\
\text { TPA }\end{array}$ & & $\begin{array}{l}\text { TPA- } \\
\text { TPS } 3\end{array}$ & $\mid \begin{array}{c}\text { Waktu } \\
\text { Letak } \\
\text { kontai } \\
\text { ner }\end{array}$ & $\begin{array}{c}\text { Waktu } \\
\text { Angkut } \\
\text { Kontain } \\
\text { er }\end{array}$ & $\begin{array}{c}\text { TPS3- } \\
\text { TPA }\end{array}$ & & & & & \\
\hline 1 & Daniel Mainake & 0.03 & 0.25 & 0.60 & 0.17 & 0.63 & 0.05 & 0.25 & 0.63 & 0.17 & 0.00 & 0.00 & 0.00 & 0.00 & 0.17 & 0.60 & 0.05 & 0.03 & 3.68 \\
\hline 2 & Frangky Sopacua & 0.05 & 0.25 & 0.68 & 0.17 & 0.67 & 0.05 & 0.25 & 0.67 & 0.17 & 0.75 & 0.05 & 0.25 & 0.5 & 0.17 & 0.68 & 0.05 & 0.05 & 5.71 \\
\hline 3 & Sutono & 0.03 & 0.25 & 0.63 & 0.17 & 0.45 & 0.05 & 0.25 & 0.45 & 0.17 & 0.00 & 0.00 & 0.00 & 0.00 & 0.17 & 0.63 & 0.05 & 0.03 & 3.34 \\
\hline 4 & Sony Wattimena & 0.03 & 0.25 & 0.75 & 0.17 & 0.75 & 0.05 & 0.25 & 0.75 & 0.17 & 0.65 & 0.05 & 0.25 & 0.65 & 0.17 & 0.75 & 0.05 & 0.03 & 5.78 \\
\hline 5 & Johais Adrians & 0.05 & 0.25 & 0.67 & 0.17 & 0.75 & 0.05 & 0.25 & 0.67 & 0.17 & 0.00 & 0.00 & 0.00 & 0.00 & 0.17 & 0.75 & 0.05 & 0.05 & 404 \\
\hline 6 & Ayub Diponegoro & 0.05 & 0.25 & 0.65 & 0.17 & 0.75 & 0.05 & 0.25 & 0.67 & 0.17 & 0.53 & 0.05 & 0.25 & 0.58 & 0.17 & 0.67 & 0.05 & 0.05 & 5.31 \\
\hline & & & & & & & & & & & & & & & & & & & \\
\hline
\end{tabular}

Berdasarkan hasil analisa pengangkutan sampah eksisting di Kota Ambon dengan Stationary Container System (SCS) dan Sistem Hauled Container System (HCS), dapat disimpulkan bahwa volume sampah terangkut dari TPS dan TPS semu adalah sekitar $450 \mathrm{~m} 3-561 \mathrm{~m} 3$.

\subsection{Proyeksi Jumlah Penduduk} rumus :

Untuk menghitung proyeksi jumlah penduduk digunakan perhitungan ekponensial, dengan

$$
P_{t}=P_{o} e^{r t}
$$

atau

Dimana :

Pt : Jumlah penduduk pada tahun ke $n$

Po : Jumlah penduduk pada tahun dasar

t : Jangka waktu

$\mathrm{r} \quad$ : laju pertumbuhan penduduk

e $\quad$ : Bilangan eksponensial $=2,718281828$ 
Data penduduk kota Ambon

\begin{tabular}{|c|c|}
\hline Tahun & $\begin{array}{c}\text { Jumlah Penduduk } \\
\text { (jiwa) }\end{array}$ \\
\hline 2012 & 354464 \\
2013 & 372330 \\
2014 & 395423 \\
2015 & 411617 \\
\hline 2016 & 427934 \\
\hline
\end{tabular}

Tabel 4.15. Data proyeksi jumlah penduduk

\begin{tabular}{|c|c|c|c|c|c|}
\hline Tahun & Po & r & e & t & Pt \\
\hline 2017 & 427934 & 0.0470905 & 2.718281828 & 1 & 448568 \\
\hline 2018 & 427934 & 0.0470905 & 2.718281828 & 2 & 470196 \\
\hline 2019 & 427934 & 0.0470905 & 2.718281828 & 3 & 492868 \\
\hline 2020 & 427934 & 0.0470905 & 2.718281828 & 4 & 516632 \\
\hline 2021 & 427934 & 0.0470905 & 2.718281828 & 5 & 541542 \\
\hline 2022 & 427934 & 0.0470905 & 2.718281828 & 6 & 567654 \\
\hline 2023 & 427934 & 0.0470905 & 2.718281828 & 7 & 595024 \\
\hline 2024 & 427934 & 0.0470905 & 2.718281828 & 8 & 623715 \\
\hline 2025 & 427934 & 0.0470905 & 2.718281828 & 9 & 653788 \\
\hline 2026 & 427934 & 0.0470905 & 2.718281828 & 10 & 685312 \\
\hline 2027 & 427934 & 0.0470905 & 2.718281828 & 11 & 718355 \\
\hline 2028 & 427934 & 0.0470905 & 2.718281828 & 12 & 752992 \\
\hline 2029 & 427934 & 0.0470905 & 2.718281828 & 13 & 789299 \\
\hline 2030 & 427934 & 0.0470905 & 2.718281828 & 14 & 827357 \\
\hline 2031 & 427934 & 0.0470905 & 2.718281828 & 15 & 867249 \\
\hline 2032 & 427934 & 0.0470905 & 2.718281828 & 16 & 909065 \\
\hline 2033 & 427934 & 0.0470905 & 2.718281828 & 17 & 952898 \\
\hline 2034 & 427934 & 0.0470905 & 2.718281828 & 18 & 998843 \\
\hline 2035 & 427934 & 0.0470905 & 2.718281828 & 19 & 1047004 \\
\hline 2036 & 427934 & 0.0470905 & 2.718281828 & 20 & 1097488 \\
\hline
\end{tabular}

\subsection{Proyeksi Jumlah Timbulan Sampah}

Tabel 4.16. Data Proyeksi Jumlah Timbulan Sampah

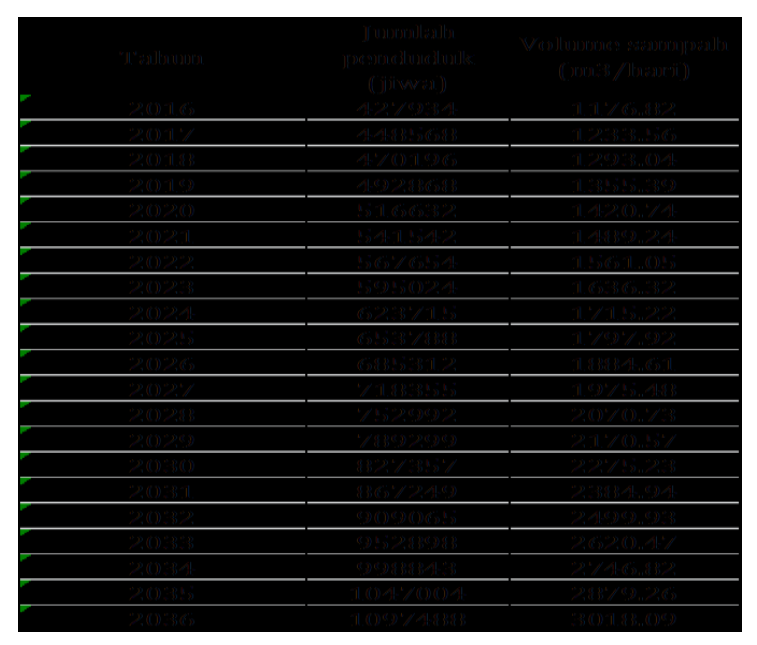

\subsection{Optimasi Angkutan Sampah}

\subsubsection{Stationary Container System (SCS)}

$>$ Dump Truck dan Pick $U p$

Untuk kecepatan kendaraan pengangkut dari TPS ke TPA dianggap konstan, berarti $\mathrm{h}=\mathrm{x}$ 


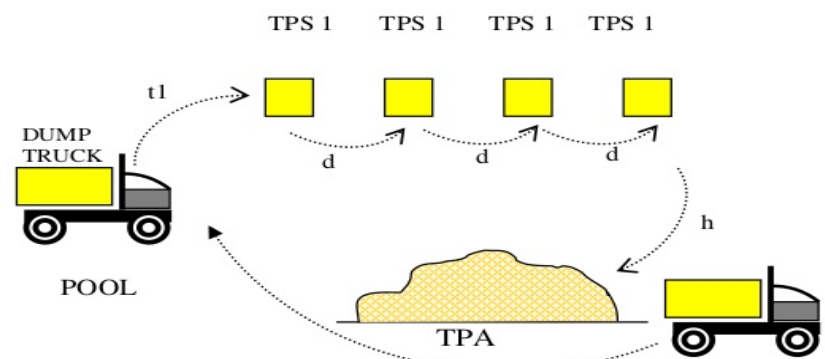

Untuk mendapatkan jumlah trip kendaraan perhari dígunakan rumus :

$$
\mathrm{Nd}=\{\mathrm{H}(1-\mathrm{W})-(\mathrm{t} 2+\mathrm{t} 1)\} / \mathrm{T}_{\mathrm{scs}}
$$

Dimana :

$\mathrm{Nd}$

$\mathrm{H}$

$\mathrm{t} 1$

t2

W

$\mathrm{T}_{\mathrm{scs}}$

Pscs

S

$X$

W

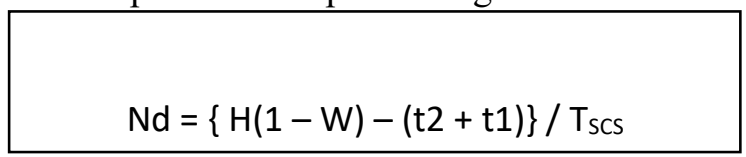

: Jumlah trip/hari

: Waktu kerja/hari

: Waktu dari pool ke lokasi pertama

: Waktu kendaraan pengangkut dari TPA ke pool

: Off route faktor

: $\mathrm{P}_{\mathrm{scs}}+\mathrm{x}+\mathrm{s}$

: waktu yang diperlukan untuk memuat sampah dari lokasi TPS pertama sampai ke TPS terakhir

: waktu rata-rata pembongkaran di TPA

: waktu tempuh rata-rata TPS - TPA

: Faktor off route $(\mathrm{w} / \mathrm{H}) \mathrm{w}=$ waktu off route(jam/hari), $\mathrm{H}=$ jam kerja (jam/hari)

\begin{tabular}{|c|c|c|c|c|}
\hline \multicolumn{5}{|c|}{ Tabel 4.17. Perhitungan Faktor off route $(W)$ kendaraan Dump truck } \\
\hline \multirow{2}{*}{ No } & \multirow{2}{*}{\multicolumn{2}{|c|}{ Uraian Kegiatan }} & \multicolumn{2}{|c|}{ Rata-rata kendaraan } \\
\hline & & & Menit & Jam \\
\hline 1 & \multicolumn{2}{|c|}{ Persiapan, checking rutin kendaraan } & 15 & 0.250 \\
\hline 2 & \multicolumn{2}{|c|}{ Sarapan pagi } & 12 & 0.200 \\
\hline 3 & \multicolumn{2}{|c|}{ Pencucian Bak, sebelum kembali ke Pool } & 12 & 0.200 \\
\hline 4 & \multicolumn{2}{|c|}{ Pengisian BBM } & 10 & 0.167 \\
\hline 5 & \multicolumn{2}{|c|}{ Ganti Ban Boocor, dll } & 15 & 0.250 \\
\hline & \multicolumn{2}{|c|}{ Jumlah } & 64 & 1.067 \\
\hline & \multicolumn{2}{|l|}{ Rasio } & & 0.15 \\
\hline & \multicolumn{4}{|c|}{ Tabel 4.18. Perhitungan Faktor off route (W) kendaraan Pick Up } \\
\hline & \multirow{2}{*}{ No } & \multirow{2}{*}{ Uraian Kegiatan } & \multicolumn{2}{|c|}{ Rata-rata kendaraan } \\
\hline & & & Menit & Jam \\
\hline & 1 & Persiapan, checking rutin kendaraan & 8 & 0.133 \\
\hline & 2 & Sarapan pagi & 12 & 0.200 \\
\hline & 3 & Pencucian Bak, sebelum kembali ke Pool & 8 & 0.133 \\
\hline & 4 & Pengisian BBM & 8 & 0.133 \\
\hline & 5 & Ganti Ban Boocor, dll & 10 & 0.167 \\
\hline & & Jumlah & 46 & 0.767 \\
\hline & & Rasio & & 0.15 \\
\hline
\end{tabular}

Berdasarkan data pada tabel 4.12 dan tabel 4.13, didapat data sebagai berikut :

\begin{tabular}{|c|c|c|}
\hline Simbol & $\begin{array}{c}\text { Dump Truck } \\
\text { (jam) }\end{array}$ & Pick up (jam) \\
\hline $\mathrm{H}$ & 7 & 5 \\
\hline $\mathrm{t} 1$ & 0.03 & 0.04 \\
\hline $\mathrm{t} 2$ & 0.54 & 0.50 \\
\hline $\mathrm{W}$ & 0.15 & 0.15 \\
\hline Pscs & 1.23 & 1.17 \\
\hline $\mathrm{s}$ & 0.25 & 0.20 \\
\hline $\mathrm{x}$ & 0.51 & 0.52 \\
\hline
\end{tabular}


Perhitungan trip kendaraan per hari dengan Stationary Conteiner System (SCS) adalah

\begin{tabular}{|c|c|c|c|c|c|c|c|c|c|c|}
\hline \multirow{2}{*}{ No } & \multirow{2}{*}{ Kendaraan } & \multicolumn{3}{|c|}{ Tscs $=$} & \multicolumn{4}{|c|}{$\mathrm{Nd}$} & \multirow{2}{*}{$\begin{aligned} \text { TSCS } & =\text { PSCS } \\
& +x+s\end{aligned}$} & \multirow{2}{*}{ 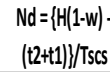 } \\
\hline & & PSCS & $x$ & $\mathrm{~s}$ & $\mathrm{H}$ & 1-W & $t 2+11$ & Tscs & & \\
\hline 1 & Dump Truck & 1.234 & 0.51 & 0.25 & 7 & 0.85 & 0.57 & 2.00 & 2.00 & 2.69 \\
\hline 2 & Pick Up & 1.17 & 0.52 & 0.20 & 5 & 0.85 & 0.54 & 1.89 & 1.89 & 1.96 \\
\hline
\end{tabular}

Dari haril perhitungan diatas, dapat disimpulkan bahwa :

1. Dengan menambah jam kerja dari 5 jam menjadi 7 jam (dump truck), pengangkutan sampah dapat dicapai 3 trip/hari.

2. Dengan menambah jam kerja dari 3 jam menjadi 5 jam (pickup), pengangkutan sampah dapat dicapai 2 trip/hari.

\subsubsection{Hauled Container System (HCS) \\ Armroll}

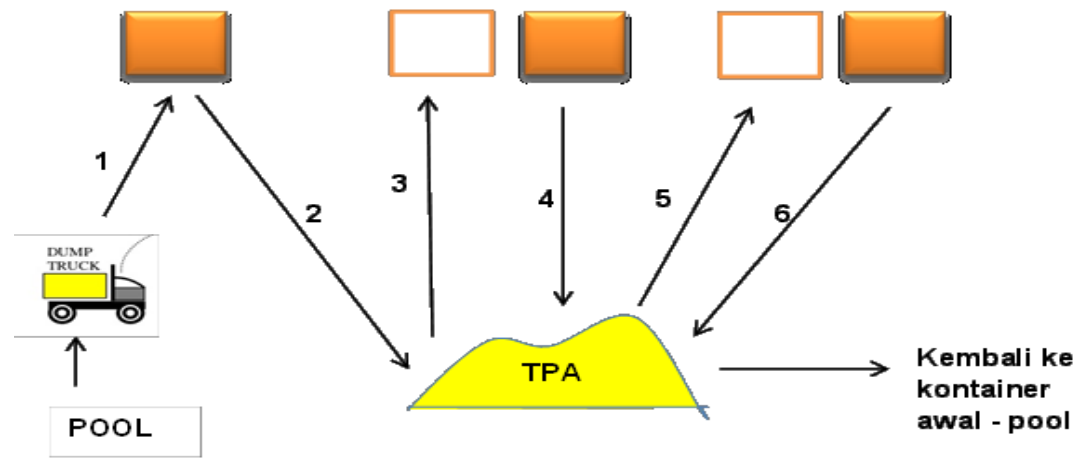

Berdasarkan data pada tabel 4.14 data sebagai berikut :

$>\quad \mathrm{h}($ waktu dari TPS ke TPA ke kontainer berikutnya $)=1,31 \mathrm{jam}$

$>\quad \mathrm{t} 1$ (waktu tempuh dari pool ke kontainer) $=0,04$

$>\quad \mathrm{t} 2$ (waktu dari TPS ke lokasi terakhir kembali ke pool) $=0,77$

$>\quad \mathrm{W}($ waktu off route $)=0,15$

$>\quad \mathrm{H}($ waktu kerja perhari $)=5$ jam

$>\mathrm{T}_{\mathrm{HCS}}=\mathrm{P}_{\mathrm{HCS}}+\mathrm{h}+\mathrm{s}$

$\quad \mathrm{P}_{\mathrm{HCS}}=\mathrm{pc}+\mathrm{uc}+\mathrm{dbc}$

Dimana :

$>\mathrm{pc}=$ waktu mengambil / mengangkat container $=0,208$

$>\mathrm{Uc}=$ waktu meletakkan kontainer $=0,04$

$>\mathrm{dbc}=$ Waktu antar kontainer $=0,542$

$>\mathrm{S}=$ waktu menunggu dan membongkar di TPA $=0,069$

Untuk perhitungan jumlah trip kendaraan perhari adalah sebagai berikut : (Enri, 2010)

$$
\mathrm{Nd}=\{\mathrm{H}(1-\mathrm{W})-(\mathrm{t} 2+\mathrm{t} 1)\} / \mathrm{T}_{\mathrm{scs}}
$$


Perhitungan trip kendaraan per hari dengan Hauled Conteiner System (SCS) adalah :

\begin{tabular}{|c|c|c|c|c|c|c|c|c|c|c|}
\hline \multirow{2}{*}{ Kendaraan } & \multicolumn{3}{|c|}{ PHCS $=$} & \multicolumn{3}{|c|}{ THCS $=$} & \multirow{2}{*}{ H } & \multirow{2}{*}{$\begin{array}{c}W \\
(1-w)\end{array}$} & \multirow{2}{*}{$\mathrm{t} 1+\mathrm{t} 2$} & \multirow{2}{*}{$\begin{array}{l}\mathrm{Nd}=\{H(1-\mathrm{w})- \\
(\mathrm{t} 2+\mathrm{t} 1)\}\} / \mathrm{Tsc}\end{array}$} \\
\hline & $p c$ & uc & $\mathrm{dbc}$ & PHCS & $\mathrm{h}$ & $s$ & & & & \\
\hline \multirow{2}{*}{ Armroll } & 0.208 & 0.04 & 0.542 & 0.79 & 1.31 & 0.17 & \multirow{2}{*}{5.00} & \multirow{2}{*}{0.85} & \multirow{2}{*}{0.81} & \multirow{2}{*}{3.92} \\
\hline & & 0.79 & & & 2.27 & & & & & \\
\hline
\end{tabular}

Dari perhitungan diatas, dapat disimpulkan bahwa jika waktu operasional armroll dioptimalkan (5 jam/hari), maka jumlah ritasi maksimum pengangkutan sampah yang dapat dicapai adalah 4 trip per hari.

Perbandingan pengangkutan sampah eksisting dan hasil optimasi dapat dilihat pada tabel berikut : Tabel 4.19. Perbandingan Jumlah Sampah terangkut Eksisting dan Hasil Optimasi Waktu Kerja

\begin{tabular}{|l|l|c|c|c|c|c|c|c|c|c|c|}
\hline \multirow{2}{*}{ No } & \multirow{2}{*}{ Kendaraan } & $\begin{array}{c}\Sigma \\
\text { Kenda } \\
\text { raan }\end{array}$ & $\begin{array}{c}\text { Jam } \\
\text { Kerja }\end{array}$ & Ritasi & $\begin{array}{c}\text { Vol } \\
\text { Sampah } \\
\text { Terangku } \\
\mathbf{t}(\mathbf{m} 3)\end{array}$ & $\begin{array}{c}\text { Total } \\
\text { Sampah } \\
\text { Terangku } \\
\mathbf{t}(\mathbf{m} 3)\end{array}$ & $\begin{array}{c}\sum_{\text {Kenda }} \\
\text { raan }\end{array}$ & $\begin{array}{c}\text { Jam } \\
\text { Kerja }\end{array}$ & $\begin{array}{c}\text { Vol } \\
\text { Ritasi } \\
\text { Sampah } \\
\text { Terangkut } \\
\text { (m3) }\end{array}$ & $\begin{array}{c}\text { Total } \\
\text { Sampah } \\
\text { Terangkut } \\
\text { (m3) }\end{array}$ \\
\hline 1 & DumpTruck & 21 & 5 & 2 & 10 & 420 & 21 & 7 & 3 & 10 & 630 \\
\hline 2 & Pick Up & 6 & 2 & 1 & 6 & 36 & 6 & 5 & 2 & 6 & 72 \\
\hline 3 & Armroll & 6 & 5 & 2 & 7 & 84 & 6 & 5 & 4 & 7 & 168 \\
\hline
\end{tabular}

Dari tabel diatas, dapat disimpulkan jika dilakukan optimasi pengangkutan sampah dengan menambah jam kerja Dump truck dan Pick up, serta memaksimalkan waktu pengangkutan sampah dengan armroll truck, maka volume sampah yang terangkut akan mengalami peningkatan dari sebelumnya, yaitu dari rata-rata $540 \mathrm{~m}^{3} /$ hari menjadi $870 \mathrm{~m}^{3} /$ hari.

\subsection{Kebutuhan Angkutan Sampah}

berikut :

Untuk mendapatkan kebutuhan angkutan sampah digunakan rumus sebagai

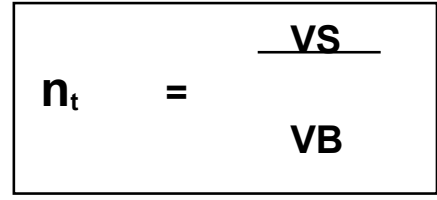

Dimana :

$\mathrm{n}_{\mathrm{t}} \quad=$ Jumlah truck yang dibutuhkan

VS $\quad=$ Volume sampah yang dihasilkan per hari

VB $\quad=$ Volume kapasitas kendaraan (m3/rit) 


\begin{tabular}{|c|c|c|c|c|c|c|}
\hline \multirow[b]{3}{*}{ Tahun } & \multicolumn{6}{|c|}{ Tabel 4.20. Proyeksi kebutuhan angkutan sampah } \\
\hline & \multirow[b]{2}{*}{$\begin{array}{c}\text { Jumlah } \\
\text { penduduk } \\
\text { (jiwa) }\end{array}$} & \multirow[b]{2}{*}{$\begin{array}{c}\text { Volume } \\
\text { sampah } \\
\text { (m3/hari) }\end{array}$} & \multirow{2}{*}{$\begin{array}{c}\text { Volume } \\
\text { sampah di } \\
\text { TPS-TPS } \\
\text { (70\%) } \\
\text { m3/hari }\end{array}$} & \multicolumn{3}{|c|}{ Asumsi Volume sampah TPS - TPA } \\
\hline & & & & $\begin{array}{c}\text { Dump } \\
\text { truck (10 } \\
\text { m3/trip -3 } \\
\text { trip) } \\
60 \%\end{array}$ & $\begin{array}{c}\text { Pick Up } \\
\text { (6m3/trip } \\
-2 \text { trip) } \\
10 \%\end{array}$ & $\begin{array}{c}\text { Armroll } \\
\text { (8 } \\
\text { m3/trip - } \\
4 \text { trip) } \\
30 \%\end{array}$ \\
\hline 2016 & 427934 & 1176.82 & 823.77 & 16 & 7 & 8 \\
\hline 2017 & 448568 & 1233.56 & 863.49 & 17 & 7 & 8 \\
\hline 2018 & 470196 & 1293.04 & 905.13 & 18 & 8 & 8 \\
\hline 2019 & 492868 & 1355.39 & 948.77 & 19 & 8 & 9 \\
\hline 2020 & 516632 & 1420.74 & 994.52 & 20 & 8 & 9 \\
\hline 2021 & 541542 & 1489.24 & 1042.47 & 21 & 9 & 10 \\
\hline 2022 & 567654 & 1561.05 & 1092.73 & 22 & 9 & 10 \\
\hline 2023 & 595024 & 1636.32 & 1145.42 & 23 & 10 & 11 \\
\hline 2024 & 623715 & 1715.22 & 1200.65 & 24 & 10 & 11 \\
\hline 2025 & 653788 & 1797.92 & 1258.54 & 25 & 10 & 12 \\
\hline 2026 & 685312 & 1884.61 & 1319.23 & 26 & 11 & 12 \\
\hline 2027 & 718355 & 1975.48 & 1382.83 & 28 & 12 & 13 \\
\hline 2028 & 752992 & 2070.73 & 1449.51 & 29 & 12 & 14 \\
\hline 2029 & 789299 & 2170.57 & 1519.40 & 30 & 13 & 14 \\
\hline 2030 & 827357 & 2275.23 & 1592.66 & 32 & 13 & 15 \\
\hline 2031 & 867249 & 2384.94 & 1669.45 & 33 & 14 & 16 \\
\hline 2032 & 909065 & 2499.93 & 1749.95 & 35 & 15 & 16 \\
\hline 2033 & 952898 & 2620.47 & 1834.33 & 37 & 15 & 17 \\
\hline 2034 & 998843 & 2746.82 & 1922.77 & 38 & 16 & 18 \\
\hline 2035 & 1047004 & 2879.26 & 2015.48 & 40 & 17 & 19 \\
\hline 2036 & 1097488 & 3018.09 & 2112.66 & 42 & 18 & 20 \\
\hline
\end{tabular}

Berdasarkan tabel diatas, dapat disimpulkan bahwa jumlah kendaraan angkutan sampah Dumpt truck saat ini sudah memenuhi kebutuhan angkutan sampah di kota Ambon untuk tahun 2018. Terdapat kekurangan 2 unit kendaraan pickup dan 2 unit kendaraan armroll truck.

\section{KESIMPULAN}

1. Volume sampah terangkut dari TPS - TPA rata-rata $540 \mathrm{~m}^{3} /$ hari dengan menggunakan 21 unit dump truck, 6 unit pick up dan 6 unit armroll.

2. Dengan penambahan jam kerja pengangkutan sampah, (dumptruck dan pickup) serta optimasi waktu kerja armroll, volume sampah yang dapat diangkut dari TPA ke TPS menjadi rata-rata $870 \mathrm{~m}^{3} / \mathrm{hari}$, dimana terjadi penambahan ritasi yaitu $3 \mathrm{kali}$ ritasi/dumptruck, 2 kali ritasi /pickup dan 4 kali ritasi/armoll.

3. Dari hasil perhitungan kebutuhan kendaraan angkutan sampah pada tahun 2018 didapat, 16 unit dumptruck, 7 unit pickup, dan 8 unit armroll. Sedangkan jumlah eksisting kendaraan angkutan sampah saat ini adalah : 21 unit dumptruck, 8 unit pickup (2 rusak), dan 7 unit Armroll (1 rusak).

4. Agar penanganan sampah dapat berjalan maksimal, diperlukan kerjasama semua stakeholder baik pemerintah maupun swasta.

\section{DAFTAR PUSTAKA}

UU Nomor 18 Tahun 2008. Pengelolaan Sampah

Permen PU No 03 Tahun 2013. Penyelenggaraan Prasarana dan Sarana Persampahan dalam Penanganan Sampah Rumah Tangga dan Sampah Sejenis Sampah Rumah Tangga.

SNI 19-2451-2002. Tata cara teknik operasional pengelolaan sampah perkotaan

SNI T-12-1991-03 Tata Cara Pengelolaan Sampah di Permukiman

SK SNI T-13-1990. Tata Cara Pengelolaan Teknik Sampah Perkotaan

Peraturan Daerah Kota Ambon Nomor 11 Tahun 2015, Pengelolaan Sampah. 
Badan Pusat Statistik Kota Ambon "Kota Ambon dalam Angka Tahun 2016"

Satker Penyehatan Lingkungan Permukiman (PLP) Provinsi Maluku. Perencanaan Teknis Manajemen Persampahan (PTMP) Kota Ambon.

Kementerian Lingkungan Hidup, Sistem Informasi Pengelolaan Sampah Nasional (SIPSN)

E. Damanhuri \& Tri Padmi, (2010), Diklat Kuliah TL-3104 (versi 2010), Pengelolaan Sampah

Tchobaroglauss Theisen Samuel, 1993, Integrated Solid Waste Management, New York

Alex S, (2012), Sukses mengelola sampah organik menjadi pupuk organik

Daniel Valerina. 2009, Easy Green Living, Bandung, Hikmah

http://www.nawasis.com/ pengelolaan-sampah.html

http://www.sanitasi.net/pengelolaan/dasar-dasar-sistem-pengelolaan-sampah.html

Rizka Andriani Mahmudah dan Welly Herumurty 2016. Analisis Sistem Pengangkutan Sampah di Wilayah Surabaya Utara. Jurnal. Surabaya: Institut Teknologi Surabaya.

Prismeida Putri Diana, 2016. Sistem Pengangkutan Sampah Berdasarkan Kapasitas Kendaraan Pengangkut dan Kondisi Kontainer Sampah di Surabaya Barat. Jurnal. Surabaya : Institut Teknologi Surabaya.s

Sodikin, 2015. Arahan dan Manajemen Pengangkutan Sampah di Kecamatan Pondok Gede Kota Bekasi. Jurnal. Jakarta : Universitas Islam Negeri (UIN) Syarif Hidayatullah Jakarta. 